\title{
The new politics of environmental degradation: un/expected landscapes of disempowerment and vulnerability
}

\author{
Anna J. Willow ${ }^{1}$ \\ Ohio State University, USA
}

\begin{abstract}
Acknowledging environmental degradation as a profoundly political phenomenon, this article examines how uninvited environmental change transforms people's understandings of and relationships to the natural world. Drawing on qualitative research conducted in a semi-remote Canadian Anishinaabe community and among Euro-American residents of Ohio who oppose local shale energy development, I trace parallels between the disempowerment and vulnerability experienced by people with very different assumptions about the world and their place in it and very different positions within the global political economic system. While environmental justice scholars have revealed compelling correlations between social and environmental inequity, I argue that investigating environmental degradation's sociocultural impacts among relatively privileged groups can encourage more dynamic explorations of conjoined environmental/social/political systems and expose ongoing structural shifts. My comparative analysis seems to suggest that ever-increasing segments of the world's population now contend with environmental challenges that they did not authorize, and do not benefit from. I thus conclude by calling for additional investigations of environmental degradation in unexpected places and the implications of extensive inequity for global sustainability.
\end{abstract}

Key words: Energy, environmental degradation, environmental justice, fossil fuels, hydraulic fracking, landscape, North America, shale gas

\section{Résumé}

Cet article examine comment les changements environnementaux sans y être invité transforme les compréhensions des gens du monde naturel. Leur relation avec la nature est également modifiée. Je reconnais la dégradation de l'environnement comme un phénomène profondément politique. Je trace un parallèle entre l'impuissance et la vulnérabilité vécue par les personnes qui détiennent des hypothèses très différentes sur le monde et de leur place dans ce monde, et qui détiennent des positions socio-économiques différentes au sein du système économique et politique mondial. J'utilise une recherche qualitative menée dans une communauté Anishinaabe canadienne, et parmi les résidents américains de l'Ohio qui s'opposent au développement de l'énergie des gaz de schiste local. Alors que les chercheurs de justice environnementale ont révélé des corrélations convaincantes entre les inégalités sociales et de l'environnement, je soutiens que l'enquête des impacts socioculturels de la dégradation de l'environnement entre les groupes relativement privilégiés peut encourager les explorations plus dynamiques des systèmes conjoints environnementaux/sociaux/politiques, et d'exposer les changements structurels en cours. Mon analyse comparative suggère qu'un nombre croissant de gens soutiennent maintenant avec les défis environnementaux qu'ils n'autorisaient pas, et qu'ils ne bénéficient pas. Je conclus en demandant des investigations complémentaires de la dégradation de l'environnement dans des endroits inattendus, et les implications de ce grande injustice pour la durabilité mondiale.

Mots clés: énergie, dégradation de l'environnement, la justice environnementale, les combustibles fossiles, la fracturation hydraulique, paysage, Amérique du Nord, gaz de schiste

\section{Resumen}

Reconociendo la degradación medioambiental como un fenómeno profundamente político, este artículo examina como los cambios medioambientales no deseados transforman el entendimiento de las personas sobre el mundo natural y su relación con este. Basándose en una investigación cualitativa realizada en la semi

\footnotetext{
${ }^{1}$ Dr. Anna J. Willow, Assistant Professor, Department of Anthropology, Ohio State University, USA. Email: willow.1 "at" osu.edu. Funding for research in northwestern Ontario was supported by a J. William Fulbright Foreign Scholarship Award. Research in Ohio was not funded by any agency or sponsor. Thankyou to two reviewers. This is the second article in Willow, A.J. and Wylie, S. (eds.) 2014. "Energy, environment, engagement: encounters with hydraulic fracking", special section of the Journal of Political Ecology 21: 222-348.
} 
remota comunidad Anishinaabe Canadiense y entre residentes americanos de Ohio, los cuales se oponen al desarrollo local energético de gas de esquisto; trazo paralelismos entre la pérdida de poder y la vulnerabilidad que sufren las personas que tienen muy diferentes nociones sobre el mundo y su lugar en él, y con muy distintas posiciones dentro del sistema político económico global. Si bien los expertos en justicia ambiental han revelado correlaciones convincentes entre inequidad social y ambiental, yo argumento que investigando el impacto sociocultural de la degradación del medio ambiente entre grupos relativamente privilegiados es posible incentivar exploraciones más dinámicas sobre sistemas conjuntos de tipo medioambiental / sociales / políticos, y revelar los cambios estructurales en curso. Mi análisis comparativo parece sugerir que cada vez más, distintos segmentos de la población mundial lidian con desafíos ambientales los cuales no han sido autorizados por ellos, y de los cuales no se benefician. De esta manera concluyo pidiendo por investigaciones adicionales sobre la degradación medioambiental en lugares inesperados, al igual que las consecuencias de la extensa inequidad para la sustentabilidad global.

Palabras claves: Energía, degradación medioambiental, justicia ambiental, combustibles fósiles, fractura hidráulica, paisaje, América del Norte, gas de esquisto.

The whole thing is so lopsided. It's like we no longer have the right to say we wanna live in a place with clean air, clean water, a clean environment.

Tish, resident of Cuyahoga County, Ohio

I'm scared of losing the quality of life that I have now. I am scared of what health effects might come. Right now the impact is just a sense of doom hovering over me.

Kyle, resident of Tuscarawas County, Ohio

I don't think I will ever feel comfortable again.

Susan, former resident of Cuyahoga County, Ohio

\section{Introduction}

These are the words of three middle-class Ohio residents struggling to make cultural sense of ongoing and impending environmental changes they feel powerless to stop. In recent years, the merger of horizontal drilling and hydraulic fracturing (often shorthanded as fracking) techniques has made the extraction of fossil fuels from deep shale rock layers feasible and lucrative. Combined with favorable economic and policy factors, this has led to shifts in energy production patterns in the United States and beyond, including a surge in natural gas development in the Marcellus and Utica shales, which underlie significant portions of Ohio (Figure 1). ${ }^{2}$ Areas once believed to contain few subsurface resources are now seen as promising industrial targets (Willow and Wylie 2014). Exploration and production zone residents are experiencing and interpreting the resource boom in very different ways (see Willow et al. 2014). Some are enthusiastic about the possibility of newfound prosperity. Many more are concerned about the long-term impacts of shale energy development, but pragmatic about its inevitability and economic importance. ${ }^{3}$ Still others view the region's current resource trajectory as a violation of their fundamental rights, an environmental and public health disaster, and an unprecedented source of anxiety and outrage.

\footnotetext{
${ }^{2}$ In the US, the combination of horizontal drilling and high-volume slick water hydraulic fracturing has resulted in a 12fold increase in shale energy production in only ten years (The Economist 2012).

${ }^{3}$ A Quinnipiac University poll conducted in January 2012 indicated that 64 percent of Ohio voters believe the economic benefits of natural gas drilling outweigh the environmental concerns, although even more poll respondents-72 percentfavor waiting until additional impact studies are completed before proceeding (see http://www.quinnipiac.edu/institutesand-centers/polling-institute/ohio/release-detail?ReleaseID=1692) [accessed April 3 2012].
} 
In this article, I consider the perspectives of Ohioans who oppose shale energy development in order to facilitate a comparative analysis of how two very different populations have responded to uninvited changes in what I call their landscapes - their processual and contextual culturally-conceived material worlds (Bender 2002; Cosgrove 1984; Hirsch 1995; Mitchell 1994; Stewart and Strathern 2003; Willow 2011).

I have spent nearly a decade of my professional life elucidating links between social inequity and environmental degradation experienced by Anishinaabe people in northwestern Ontario as they cope with industrial mercury contamination and logging within their traditional territory (Willow 2009, 2011, 2012). ${ }^{4}$ Comprehending indigenous efforts to protect the boreal forest remains an ongoing project. But I couldn't ignore what was taking place where I teach and live for much of the year. And so, I began a series of indepth conversations with grassroots anti-fracking activists, members of environmental nonprofit organizations, and community leaders in order to ascertain how shale energy development is altering Ohioans' understandings of the world they live in. My new project made use of very different qualitative methods, took place in very different settings, involved very different types of relationships between myself and those I sought to learn from, and was punctuated by very different rhythms of life. ${ }^{5}$ Consequently, the stories I am able to tell about environmental degradation in Ontario and Ohio also differ (Figure 2).

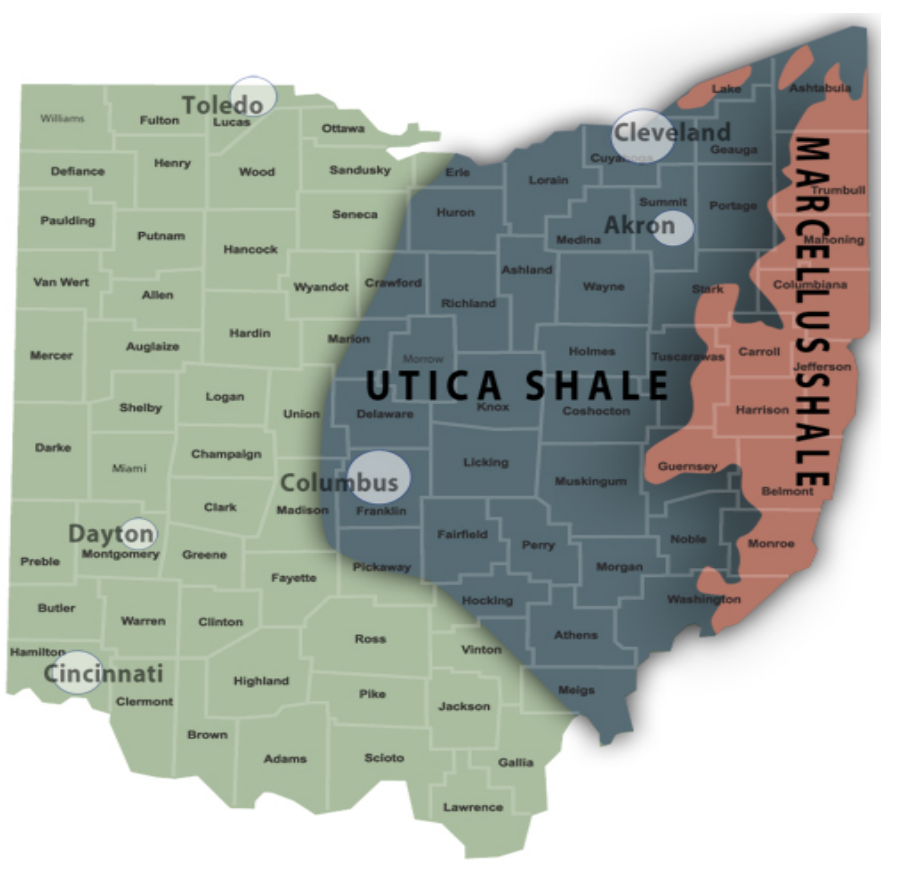

Figure 1: Zones of shale energy potential in Ohio. Source: http://www.epa.state.oh.us/MarcellusandUticaShale.aspx [accessed December 24 2012]

I was immediately struck by how similar the statements of middle-class, Euro-Americans struggling to prevent (or at least come to terms with) shale energy development sounded to ones I had heard almost a decade earlier among indigenous Canadians. Why, I had to stop and ask myself, was I so surprised by this convergence? Even as we work to bring an end to environmental manifestations of injustice, environmental

\footnotetext{
${ }^{4}$ Anishinaabe is a self-designation used by the group of people also known in the anthropological literature as Ojibwe and Chippewa.

${ }^{5}$ I conducted eleven months of full-time participant-observation in northwestern Ontario between 2003 and 2005 with the goal of learning about ongoing Anishinaabe anti-clearcutting activism at Grassy Narrows First Nation and the historical, cultural, and political factors that inspired it. While this work relied on the close relationships and emplaced understandings characteristic of long-term ethnographic fieldwork, my work in Ohio was explicitly multi-sited and included semi-structured interviews with numerous individuals from different parts of the state.
} 
social scientists have become somewhat used to seeing peoples who are marginalized or peripheral bearing a disproportionate share of global capitalism's environmentally damaging byproducts. Fighting this problematic pattern is, after all, what the environmental justice movement is all about. We know we can't understand human-environment interactions without taking complex power-structural relationships into account, but we just don't expect to see these patterns showing up in communities usually seen as privileged.

In the pages that follow, I trace parallels between how people with very different assumptions about the world and their place in it - and very different positions within the global political economic systemrespond to imposed environmental change. I first recount the story of Grassy Narrows First Nation, a small Anishinaabe community in northwestern Ontario that has confronted a long line of detrimental environmental impacts. I then return to Ohio to consider how individuals who oppose shale energy development describe this trend's transformative influence on their views of and relationships to the environment. Acknowledging environmental degradation as a profoundly political phenomenon, I propose that even as distinctive historical and cultural contexts set these situations apart, common perceptions of disempowerment and vulnerability seem to suggest extensive systemic changes, as growing numbers of people from increasingly diverse walks of life are now being forced to face immediate-and often very serious-environmental challenges that they did not authorize and do not benefit from.

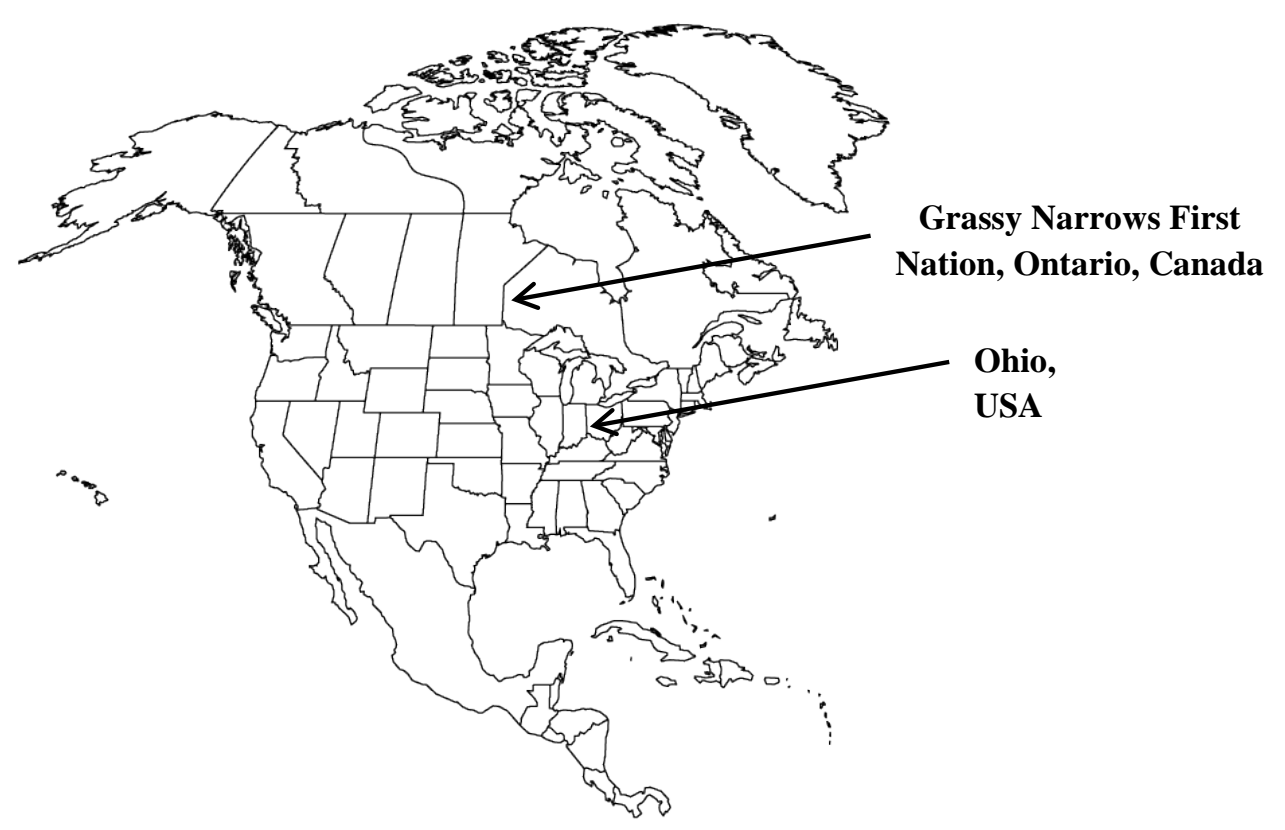

Figure 2: I conducted research in Grassy Narrows, Ontario between 2003 and 2005 and in multiple locations in the state of Ohio in 2012. Source: Base map from http://www.worldatlas.com [accessed November 25 2013].

\section{The politics of environmental degradation}

Environmental degradation disrupts geophysical processes and transforms ecosystems, but neither its causes nor its effects are confinable to the material world (Blaikie and Brookfield 1987). ${ }^{6}$ Indeed, the impacts of environmental degradation extend far beyond the physical environment and into the realm of

\footnotetext{
${ }^{6}$ Environmental degradation is here used to indicate a decline (or series of interrelated declines) in the quality and integrity of natural resources - and therefore in the environment's ability to sustain current life conditions - that is intentionally or inadvertently caused by human actions. Although pollution - the introduction of harmful chemicals or contaminants into the environment-is the most significant type of degradation in the two cases presented here, the political ecological process of pollution is similar to and often co-occurs with other environmental degradation events.
} 
social and cultural life (Homer-Dixon 1994; Oliver-Smith 1996). Given that "human environmental crises emerge as a result of the culture and structure of power as well as the biophysical implications of political economic action" (Johnston 1997:19), environmental degradation has been—and must be-approached politically.

Environmental degradation is as much about relationships between people as about humanenvironment relationships. Based on his observations of Yonggom people's responses to severe contamination caused by the Ok Tedi copper mine in Papua New Guinea, for example, Stuart Kirsch argues that "pollution is a kind of social relation" (2006:25). Fittingly, he notes, Yonggom people turn to indigenous interpretations and explanations to understand the mining company's behavior, often equating its "failure to acknowledge its relationships to the people living downstream" with the kind of actions customarily associated with human sorcerers (2006:120). The experiences of Argentine shantytown residents living in the shadows of petrochemical industrial activity - a site where individuals simultaneously confront compromised physical health, uncertainty about toxic exposure and its effects, and doubt regarding their status as full and equal citizens deserving of basic protections-have also been recognized as "socially and politically produced" (Auyero and Swistun 2009:5).

Merging classic ethnography's intense local focus and comprehensive cultural contextualization with political ecology's critical attention to the power structures that permeate human-environment relationships (e.g., Biersack and Greenberg 2006; Robbins 2004), anthropologies of environmental degradation have illuminated disparities in environmental decision-making ability and unequal distributions of costs and benefits associated with environmental change. Social scientific accounts of environmental degradation have also taken inspiration from world-systems analysts' recognition that even as raw materials and labor are extracted from zones of "peripheral" production, wealth and power tend to concentrate in consumptive "cores" (Wallerstein 1974, 2004; see also Friedman 1994). The inherently unequal relationships that make global commodity chains possible also allow decision-makers to distance themselves from the consequences of their actions by "siting hazardous activities and storing hazardous wastes in "peripheral" regions," both in the standard geographic sense of the word and in terms of the cultural distance constructed between members of empowered and disempowered groups (Johnston 1997:15). Recent studies of communities coping with environmental degradation in the United States (Checker 2005; Pulido 1996), Canada (VanWynsberghe 2002; Willow 2012), South America (Auyero and Swistun 2009; Reed 2008; Sawyer 2004), Africa (Omoweh 2005), India (Fortun 2001), Malaysia (Brosius 2006), and Melanesia (Biersack 2006; Kirsch 2006) underscore the inseparability of environmental and sociopolitical manifestations of inequity as well as the global systemic causes of local environmental degradation.

Scholarship on the related topics of disaster and risk has also shed light on the sociopolitics of environmental change. ${ }^{7}$ Once viewed as exceptional acts of fate, researchers now acknowledge natural disasters as outgrowths of a society's conditions of inequity and subordination rather than any incidental geophysical features of a place (Oliver-Smith 2009:13; see also Button 2010; Oliver-Smith 1996). Both between and within social groups, it has become evident that people often experience disasters (including the kind of chronic industrial impacts addressed in this article) in very different ways. Social systems differentiate individuals along axes of class, race, ethnicity, gender, and age, creating uneven patterns of vulnerability that place people at "different levels of risk from the same hazard" (Oliver-Smith 2009:14; see also Pelling 2001).

In the context of an occurring or impending disaster-whether considered natural (i.e., earthquakes, hurricanes, floods) or unambiguously derived from human activities (i.e., nuclear accidents, oil spills, toxic contamination)_power relationships and arrangements become "more clearly perceived and confronted" (Oliver-Smith 1996:309; see also Oliver-Smith and Hoffman 2002). As disaster anthropologist Gregory Button attests:

\footnotetext{
7 In recent anthropological research, the term disaster has been broadly defined as "a process/event involving a combination of a potentially destructive agent(s) from the natural and/or technological environment and a population in a socially and technologically produced condition of environmental vulnerability" (Oliver-Smith 1996:305).
} 
Disaster events highlight ongoing power struggles in society. The control of information in the media or in public discourse, as well as the attempt to control the social production of meaning, is an attempt to define reality in accordance with a favored political agenda and therefore must be seen as a distinctly ideological process (2002:146). ${ }^{8}$

The political qualities of modern technological risks and disasters are especially conspicuous. As Ulrich Beck has argued, even the most devastating pre-industrial hazards originated outside of human society and were accordingly attributable to a non-human other (whether in the form of god/s, demons, or "nature") at which accusations could be directed. Industrial hazards, on the other hand, are created by human actors. As Beck avows, "it is not the number of dead and wounded, but rather a social feature, their industrial selfgeneration, which makes the hazards of mega-technology a political issue" (1992: 98). "Hazards of the nuclear and chemical age," he adds, "have a social as well as physical explosiveness" (1992:104). The perceived threat of technological hazards-distinguished by the culpability of human agents-has engendered a citizenry highly conscious of the pervasiveness of risk and wary of modernity's "dark side" (Giddens 1990:9; see also Wakefield and Elliott 2000). ${ }^{9}$ Who, we now ask, reaps the benefits of environmental change? Who bears the burdens? Who makes critical determinations about when, where, and how industrial development and its environmental consequences occur?

Studies that map complex connections between social injustice and environmental degradation have most frequently focused on groups already known to be marginalized and disadvantaged in multiple ways. Yet even as they construct narratives of dramatic events and trace outcomes over time, researchers have often overlooked the potential of environmental degradation to indicate groups' changing status and help us identify associations among novel impacts, increasing inequities, and structural transformations. In other words, environmental degradation has long been correlated with a (troubling) lack of change in the sociopolitical status quo, but the potential of environmental degradation to alert us when (equally troubling) changes are underway has received relatively little attention. While the targeted gaze of environmental justice research has necessarily cropped privileged groups from its picture, I argue that investigating the impacts of uninvited environmental change among those for whom disempowerment and vulnerability are new experiences can encourage more dynamic explorations of conjoined environmental/social/political systems. Asking who benefits, who decides, and who suffers from environmental degradation not only reveals existing inequities, but also has the capacity to expose ongoing structural shifts. So that readers can better appreciate this argument, I begin with an overview of the established pattern of environmental injustice, as illustrated by the recent history of one group for whom environmental degradation has become an expected element of life.

\section{Expected but not accepted: environmental injustice at Grassy Narrows First Nation}

The Environmental Justice Movement (EJM) coalesced in the 1980s in response to mounting evidence that disadvantaged minority communities very often experience disproportionately degraded environments (e.g., Bullard 1990, 2005; Cole and Foster 2001; Gottlieb 1993; Martinez-Alier et al. 2014). Built upon the social justice scaffolding of the civil rights movement, EJM participants from diverse backgrounds interpret the environment as a conduit not only for the circulation of toxic poisons, but also for "the social poison of racial discrimination" (Checker 2005:103; see also Cole and Foster 2001; Edwards 1995). Targeted for locally-unwanted land-uses and externally-imposed resource-extractive projects, indigenous activists seeking support for struggles that fuse environmental, cultural, and political issues have been drawn to the EJM and

\footnotetext{
${ }^{8}$ Button noted this in the wake of the 1989 Exxon-Valdez oil spill. Kim Fortun (2001) similarly describes how activist groups resisted the "naturalization" of the 1984 chemical leak in Bhopal, India in their attempts to hold industrial decision-makers accountable.

${ }^{9}$ Although risk society is typically associated with Western populations, Kirsch (2006) discusses the advent of an "indigenous risk society" among the Yonggom in New Guinea.
} 
its discursive framework. ${ }^{10}$ Tailoring the EJM's essential appreciation of the inseparability of environmental integrity and human wellbeing to fit a Native North American context, Cherokee scholar and author Jace Weaver argues that "environmental devastation is simply one manifestation of the colonialism and racism that have marked Indian/White relations since the arrival of Columbus in 1492" (2010:26).

The long history of environmental degradation at Grassy Narrows First Nation-the site of much of my own ethnographic fieldwork as well as the longest-standing anti-logging blockade in Canadian historyepitomizes a pattern that has played out across North America (Grinde and Johansen 1995; LaDuke 1999; Weaver 1996) and around the world (Johnston 1994, 1997). With approximately 850 on-reserve citizens, Grassy Narrows is a semi-remote Anishinaabe community situated some fifty miles north of Kenora (a picturesque timber and tourism town on the Lake of the Woods' north shore) at a northern terminus of Ontario's paved road network. Like other indigenous Canadians, Grassy Narrows residents have been impacted by colonial, assimilatory, and at times blatantly racist policies (Willow 2012; see also Cairns 2000; Erasmus and Sanders 1992; Miller 1991). More than most, they have had to contend with serious environmental crises that have harmed human health and disrupted interpersonal relationships, subsistence patterns, and traditional spirituality.

I first traveled to Grassy Narrows in May of 2003, just five months after residents initiated a blockade they hoped would bring an end to the industrial clearcutting devastating large portions of their 2,500-squaremile traditional territory. I discovered that protecting the environment was only part of a complex equation; stopping clearcutting was also about sustaining Anishinaabe land-based subsistence culture and about asserting political rights. In 1873, the First Nation's forefathers signed Treaty Three, which guaranteed that Anishinaabe signatories and their descendants would "have right to pursue their avocations of hunting and fishing throughout the tract surrendered" (Canada 1966 [1871-4]:5). Because it impeded their ability to practice traditional land-based subsistence, Grassy Narrows activists argued that clearcutting violated these treaty-guaranteed rights as well as their human right to exist under conditions of their own choosing. I also learned that environmental degradation had influenced how First Nation residents understand the natural world and their relationships within it.

The people of Grassy Narrows saw their immediate environment altered without their consent for the first time in the late 1920s. Hydroelectric dams were constructed along the English River-which flows through the heart of the First Nation's homeland - to generate power for Euro-Canadian settlements and industries (Kenora Daily Miner and News Staff and the Canadian Press 1984). These dams led to localized flooding and unpredictable water-level fluctuations that still sporadically destroy wild rice crops. Then, in 1970, mercury was detected in the river (see Erickson and Vecsey 1980; Shkilnyk 1985; Troyer 1977; and Willow 2012 for more details). Beginning in 1962, roughly ten tons of the toxic substance had been released in the effluent of a pulp and paper mill owned by Reed Limited and located in far-upstream Dryden, Ontario. First detected by a graduate student investigating the effects of industrial discharges on fish, laboratory results confirmed the presence of mercury in March of 1970. Several weeks later, Ontario's Minster of Energy and Resource Management ordered the mill to stop all discharge of mercury into the river (Troyer 1977). But by then it was far too late. As the water flowed on, mercury had already bioaccumulated in the tissues of small aquatic organisms, fish, and eventually Anishinaabe people.

In addition to damaging the region's ecosystems in ways that may never be fully known, mercury contamination adversely impacted the health of the English River watershed's indigenous inhabitants and severely impaired local economic activities. Informed of the situation by provincial officials who urged them to stop consuming fish, Grassy Narrows residents began to correlate the unusual medical symptoms they and their loved ones had suffered in recent years with the presence of pijibowin-poison. ${ }^{11}$ Cases of acute mercury poisoning were documented in families that consumed large quantities of fish. Compounding

\footnotetext{
${ }^{10}$ For EJM participants, the term environment evokes not the distant natural areas and endangered ecosystems emphasized by mainstream environmentalists, but instead refers to places people live, work, and play and therefore interweaves ecosystemic issues with matters of social justice, economic and community sustainability, and human health.

${ }^{11}$ The symptoms of mercury poisoning include numbness, joint pain and cramps, tremors, tunnel vision, loss of balance, and hearing and speech impairment. Because these symptoms can have other causes, however, diagnosis in hindsight is rarely possible (Harada et al. 2005).
} 
mercury's health effects, by the 1970s many individuals at Grassy Narrows earned wages as commercial fishermen or guides for fishing tourist outfitters. Both of these opportunities dissolved abruptly when the contamination became public knowledge. Unemployment skyrocketed and formerly independent families became reliant on government assistance for the first time.

The cultural consequences of contamination were also significant. People at Grassy Narrows felt powerless to control their situation. Their customary comprehension of human-environment relationships taught that respectful reciprocity with powerful "other-than-human persons" was necessary to the achievement of bimaadiziwin — a good life free of illness and misfortune (Hallowell 1955, 1975; Nesper 2002). ${ }^{12}$ But mercury contamination defied patterns of explanation and socionatural order that had served them well in their boreal forest homeland for thousands of years. Human beings, distant both geographically and culturally, had unleashed the toxins that were now disrupting Anishinaabe lives. Most individuals at Grassy Narrows had no knowledge of the Dryden mill and no use for its products. They had done nothing to upset their delicately balanced relationship with the natural world nor to diminish the river's capacity to sustain life.

Over time, feelings of disempowerment turned to anger directed at a colonial political structure that placed the earnings of powerful industries above the wellbeing of indigenous populations. In 1977, Chief Simon Fobister told a reporter that if Grassy Narrows were a White community, "things would be different" (Rebuffoni 1977:10). Although a settlement was reached in 1986 that required Reed Limited to pay C\$16.6 million (US\$14.98m) to establish a compensation fund for contamination victims (Canada 1986; Kenora Daily Miner and News 1986), this sentiment remains ubiquitous after more than thirty years of frustrated hindsight. When, in 2005, I suggested that perhaps the mill's managers had simply been unaware of the disastrous consequences of their actions, my Anishinaabe friends made it clear that they were unwilling to excuse the contamination as a mere mistake or oversight. ${ }^{13}$ In the era of mercury, the environment is an actual and potential site of sociopolitical inequity—a place where injustice is enacted, revealed, and written on the landscape (Willow 2009:55).

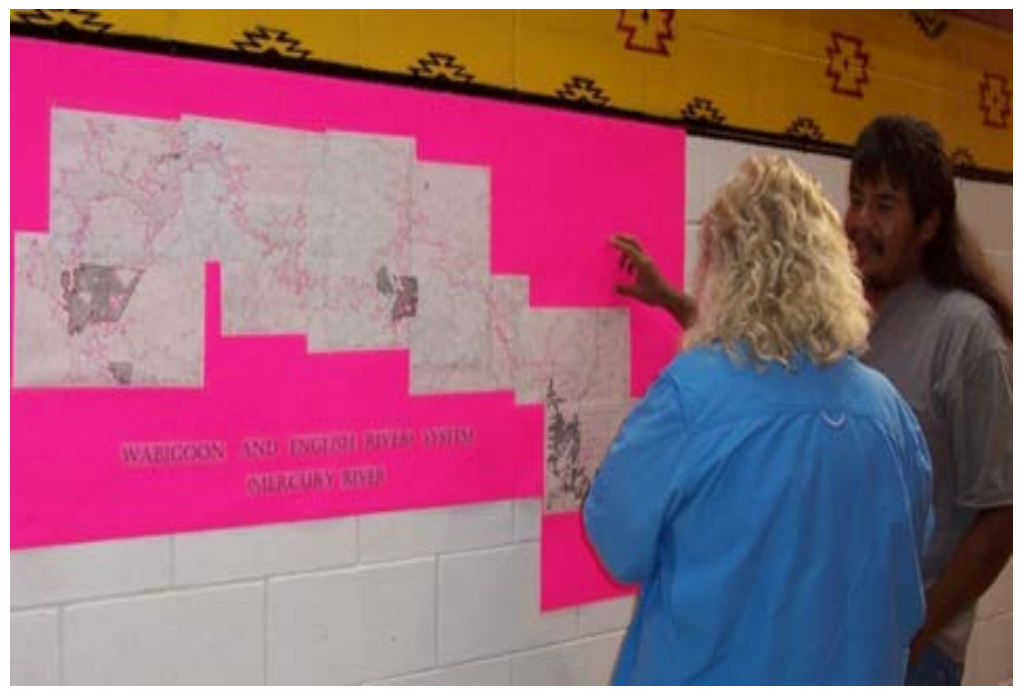

Figure 3: A Grassy Narrows First Nation resident teaches a visitor about mercury contamination. The words on the homemade poster read, "Wabigoon and English River System: Mercury River." August, 2004 (photo by author).

\footnotetext{
${ }^{12}$ This term has been spelled in various ways, including pimmädäzīwin (Hallowell 1955, 1975) and pimadiziwin (Nesper 2002). I use the double-vowel spelling found in Nichols and Nyholm's Concise Dictionary of Minnesota Ojibwe (1995).

${ }^{13}$ Fieldnotes, Jan 18, 2005.
} 
Grassy Narrows residents experienced new kinds of vulnerability as a result of mercury contamination. The river they had trusted for generations to provide for their people became a source of pijibowin and site of trepidation. Instead of offering nourishment and the satisfaction of self-sufficiency, the river could now make them sick (Figure 3). ${ }^{14}$ Today, a disconcerting number of Grassy Narrows residents are able to recite offhand the parts-per-billion (ppb) of mercury in their own bodies. ${ }^{15}$ And, as they have now for decades, subsistence harvesters must continuously weigh the economic and cultural benefits of consuming wild foods against the known physical risks. ${ }^{16}$ Not only do contemporary First Nation residents live with the constant anxiety of environmental degradation's embodied effects, but mercury contamination also led, I think for the first time, to an understanding of the environment as broadly susceptible to extensive anthropogenic damage. Not only could human bodies now succumb to frightening environmental maladies, but Anishinaabe principles of socionatural reciprocity were adapted to accommodate a new industrial regime, implying that the environment itself was now both amenable to and in need of human protection (see Willow 2009).

Industrial clearcutting, which intensified throughout northwestern Ontario in the 1990s, is the latest environmental injustice to beset Grassy Narrows. Concerned for current and future citizens, frustrated by the surrounding settler society's consistent refusal to recognize their role as landowners, and primed by their earlier experiences, a growing number of First Nation residents felt by 2002 that urgent action was needed to protect their health and culture. Even as they envisioned and presented themselves as environmental defenders, their direct action against clearcutting took place in a political landscape, a place where lack of concern for environmental integrity could not be disentangled from lack of concern for the lives and livelihoods of the people who inhabit and directly depend upon a now degraded environment. While the particulars of the Grassy Narrows case are unique, scholars and activists working around the world have demonstrated that people who are already disadvantaged confront disproportionately degraded environments; as we have seen, members of indigenous and minority groups cope with the detriments of industrial activity but enjoy few of its benefits. It is with this well-established pattern-exemplified by events and experiences at Grassy Narrows First Nation-in mind that we return to shale energy development Ohio.

\section{Environmental degradation in unexpected places: shale energy development in Ohio}

Worldwide, residents of areas with underlying unconventional fossil fuel deposits are witnessing dramatic increases in rates of energy exploration and production. ${ }^{17}$ Eastern Ohio is one of these areas (see Figure 1). ${ }^{18}$ Corporate agents-usually referred to as landmen-are canvassing promising areas and securing leases granting subsurface rights to oil and gas companies ranging from small local operators to major multinational players. In exchange, landowners typically receive a signing bonus and the promise of royalties should a well on the property prove productive, although the amount of these payments varies considerably. If and when a company chooses to drill, the ecological footprint is often immense. With contractors hired to carry out various stages of the process, several acres are cleared of vegetation and leveled. Access roads are constructed and/or upgraded to facilitate the movement of heavy industrial equipment (i.e., drills, pumps, generators, and storage tanks) to the site. When a well is fracked, large

\footnotetext{
${ }^{14}$ As Ronald Niezen hypothesizes regarding hydroelectric development and mercury contamination experienced by James Bay Cree (a group related linguistically and culturally to the Grassy Narrows Anishinaabe), "such dramatic changes to the land as flooding and contamination of fish can only lead to a sense of sorrow or spiritual malaise among those accustomed to a careful scrutiny of human relationships with animals and the environment" (1998:88).

${ }^{15}$ Fieldnotes, June 17, 2004.

${ }^{16}$ Fieldnotes, June 2, 2003.

${ }^{17}$ The term unconventional is used to distinguish natural gas and oil extracted from shale formations, tight gas sands, and coal seams using recent technological innovations.

${ }^{18}$ Shale energy development in Ohio is in an early stage compared to plays in Pennsylvania, Texas, and the American West. As of November 2013, Ohio had 627 horizontal wells drilled, but this number is projected to rise rapidly. For updates on shale development in Ohio, see http://www.ohiodnr.com/oil/shale/tabid/23174/Default.aspx

[accessed November 29 2013].
} 
quantities of fracking fluid-composed of water, proppants, and a wide array of potentially hazardous chemicals - are transported by truck and pumped into the ground at high velocity. A considerable amount of research investigating the environmental and economic impacts of this kind of activity is underway (e.g., United States Environmental Protection Agency 2012). Even as unconventional energy has begun to attract the attention of social scientists, however, documentation of shale energy's sociocultural consequences remains scarce in comparison (at the time of this writing, key recent publications on the topic include Cartwright 2013; de Rijke 2013a, 2013b; Finewood and Stroup 2012; Hudgins 2013; and Perry 2011, 2013).

Throughout 2012, I engaged in participant-observation research in public locations where discussions about shale energy were occurring and conducted open-ended interviews with nineteen grassroots antifracking activists, nonprofit organization affiliates, and community leaders who held divergent perspectives regarding the ongoing resource rush. Publicly-available statements produced by the oil and gas industry to address social and environmental elements of corporate responsibility were also reviewed. As detailed in Willow et al. (2014), content coding of transcribed interviews and industry documents revealed six themes used to describe how ways of experiencing and imagining the environment are changing as a result of ongoing or impending natural gas extraction: legacy, way of life, disempowerment, vulnerability, displacement, and prosperity. This analysis suggested that people who are differently positioned in relation to shale energy development are making cultural sense of Ohio's changing environment in very different ways, which appear to be rooted in dissimilar understandings of human-environment relationships and influenced by contemporary sociopolitical arrangements that guide environmental policy and industry activity (Willow et al. 2014).

I was struck by the fact that every single grassroots anti-fracking activist I interviewed talked extensively about the disempowerment and vulnerability they were experiencing as a result of extractive activities occurring-sometimes almost literally_in their backyards. Ohio has seen major protests surrounding the escalation of shale energy development, both at the statehouse in Columbus and at countless local demonstrations and meetings. Anti-fracking activists have also generated a strong internet presence, with numerous webpages and Facebook interfaces designed to inform concerned citizens about the environmental and human health risks associated with fracking. While organized environmental groups have gotten involved in the ongoing debate about Ohio's energy future, many of the individuals I spoke with had never previously participated in environmental campaigns and did not identify themselves as environmentalists. They were property-owners, parents, and professionals who felt personally threatened by what they observed taking place around them. Some of the most striking stories came from residents of Broadview Heights (Cuyahoga County), a prosperous outer-ring suburb of Cleveland that has nearly ninety oil and gas wells within a 13.1-square-mile area. In other places, people who have yet to be directly impacted discussed similar sentiments, usually in anticipation of imminent drilling development. In this section, I summarize the stories and statements shared by anti-fracking activists in order to shed light on the experiences and effects of a new kind of environmental degradation. ${ }^{19}$

I found that people who oppose shale energy development associate it with strong feelings of disempowerment. In fact, disempowerment has been routinely reported in communities with existing or potential environmental hazards, alongside threats of "physical harm, financial ruin, disruption of social networks, and a loss of personal control" (Rich et al. 1995:658). For impacted individuals, the "sense of powerlessness is often amplified by the fact that neither flight nor fight is possible (Rich et al. 1995:663). All of these concerns are relevant in Ohio and were raised repeatedly by anti-fracking activists. In addition to describing declining home values, disputes between neighbors who have leased their land and those who have not, and fears for physical safety (discussed extensively below), people said they no longer have the ability to determine what takes place in their immediate environment-both on and around their own

\footnotetext{
${ }^{19}$ Energy development is new to some parts of Ohio, but other areas have a long history of coal extraction and conventionally-produced oil and natural gas. While outside the scope of the present article (but a fruitful topic for future research), historical patterns of extraction appear to play a complex role in shaping contemporary attitudes (Hudgins 2013). One interviewee from Tuscarawas County-an established coal mining area-compared the impending environmental and social impacts of shale energy development to those of coal, stating "the scars of the coal industry are just now starting to heal. I feel like we're reopening a wound" (Kyle, interview, February 6, 2012).
} 
properties and in the communities they call home. They argued that the activities of a powerful industry are infringing on fundamental rights and undermining core democratic values. Some framed access to clean air and water as a civil right that is now being flagrantly disregarded. Tish, a middle-aged woman from Broadview Heights who has spoken out publically against local shale energy development, put it this way:

Here's the thing. Our basic civil rights to clean air, clean water, and a safe environment that we as Americans enjoy...have been taken away from us and nobody has a right to do it. It's basically, in one word to sum it up, it's just been a nightmare. ${ }^{20}$

Kyle, a writer from Tuscarawas County, summarized the situation by declaring, "I feel very violated as a citizen of the state of Ohio." ${ }^{21}$

I was initially surprised to find that many anti-fracking activists-themselves mindful consumers of fossil fuel resources - do not believe shale energy development should be altogether abandoned. In common with a large segment of the American public, they see benefits in domestically-produced affordable energy, both as individual consumers and for the national economy. While several people I spoke with did list carbon emissions/climate change as a detrimental outcome of fracking, this issue has not emerged as a major motive for grassroots opposition and is only one of many arguments articulated by nonprofit organizations. Echoing the emphasis on an integral, surrounding "ambient" rather than a discreet, distant "environment" noted by Michael Edelstein in his study of communities coping with toxic contamination (2004:82-84), the anti-fracking-movement in Ohio and elsewhere takes its primary impetus from immediate environments and personal impacts rather than from the abstract global predicaments of Anthropocene life. Time and again, I heard concerned Ohioans say they might be willing to support increased energy development in rural areas, if landowners received full and accurate information to guide their decisions, if all impacted parties consented. But this is not how things are playing out. The inability of local municipalities and individual landowners to decide when and where such development occurs was noted as a matter of critical concern. Individuals I interviewed made sure I was aware of legislation passed in 2004 that granted the state's Department of Natural Resources (Division of Mineral Resources Management) "sole and exclusive authority to regulate the permitting, location, and spacing of oil and gas wells within the state" (Ohio Substitute House Bill Number 278 2004:Sec 1509.02), thus negating municipal- and county-level zoning that could limit energy development. Currently facing an initial legal challenge in Ohio's highest court (Cocklin 2013), this bill has augmented Ohioans' feelings of disempowerment. As Cheryl, a resident of Union County, explained:

I find it horrifying that my family and my land that I try to nourish could be impacted by something like that. And there's nothing that myself or anybody in my community has the ability to control. The only entities that have any control over this are the oil and gas industry and the state government. ${ }^{22}$

Several activists additionally mentioned the matter of mandatory pooling. In dozens of cases, this legal mechanism has been deployed to force landowners to include their properties in the acreage required for a new well to be drilled. ${ }^{23}$ As a result, active wells now exist in plain sight of homes occupied by people who adamantly oppose them. With individual and local control subverted, wells are being drilled and fracked in residential areas, adjacent to public schools and playgrounds (Figure 4), and in the center of some towns.

\footnotetext{
${ }^{20}$ Interview, February 15, 2012.

${ }^{21}$ Interview, February 6, 2012.

${ }^{22}$ Interview, January 18, 2012.

${ }^{23}$ For information on mandatory pooling legislation in Ohio, see

http://www.dnr.state.oh.us/mineral/mandatory_pooling/tabid/19234/Default.aspx [accessed December 122012 ].
} 


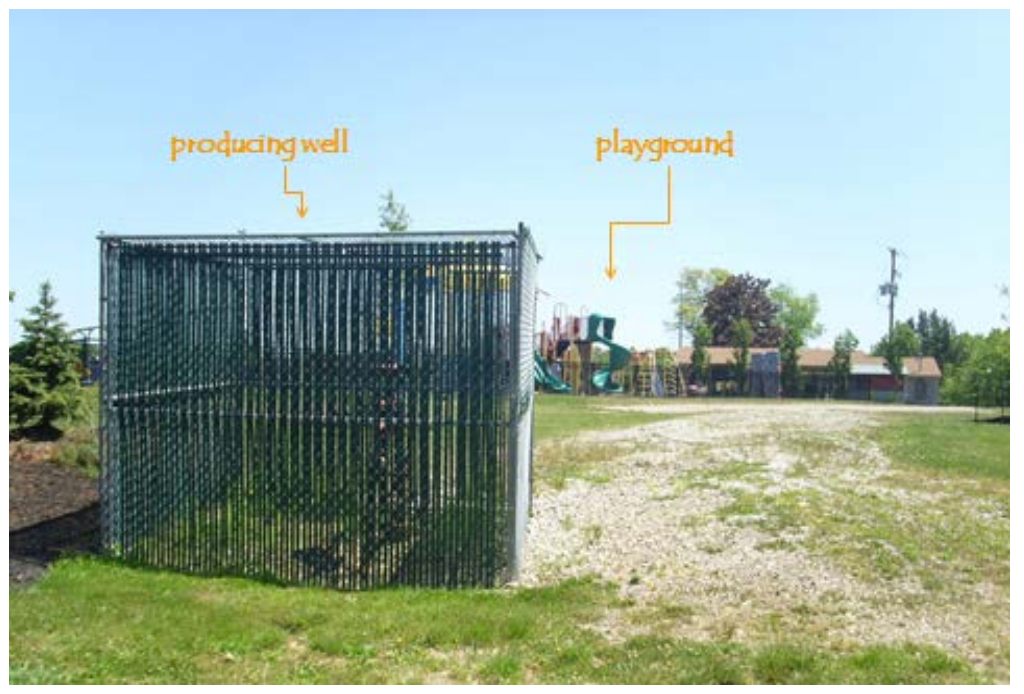

Figure 4: A well and playground in Broadview Heights, Ohio. April, 2012 (photo by author).

In addition to invoking legal and civil rights discourse in their discussions of disempowerment, antifracking activists described their experiences in other ways that revealed the complexity and intensity of their interests. In some cases, the same individuals who enumerated problems with state legislation and its implementation also shared highly personal stories. Michelle, the co-founder of a group called MADION (Mothers Against Drilling in Our Neighborhoods) and also a Broadview Heights resident, recalled her exhausting struggle to obtain accurate information about when a well 600 feet (183 meters) behind her home would be fracked and what chemicals would be used. ${ }^{24}$ She told me about the anxiety that now prevents her young son from playing outdoors, about the foul-smelling gas that saturated her neighborhood one evening, about the evacuation plans she put in place and mentally rehearsed. And, tearfully, she told me about sitting, awake and afraid, in her living room late into the night when the well was drilled. That night, she said, was

...the first time ever that I felt I had absolutely no control of keeping my child safe. Cause they took it away from me. The governor took it away from me, the ODNR [Ohio Department of Natural Resources] took it away from me, and [the company] took it away from me. And that is my job, to keep my child safe. ${ }^{25}$

With equal passion, Susan, a former Broadview Heights resident who relocated to another state to protect her family from the impacts of shale energy development, discussed how she felt after three wells were installed behind her home. As she bitterly recalled, "...it was devastating. I don't know how to describe it any other way. It was like being under siege." ${ }^{26}$ While seldom so emotionally poignant, other activists I met discerned equally negative correlations between their own wellbeing and ongoing shale energy extraction. Many expressed exasperation that business, property, and investment decisions made several years ago are no longer sound, due to no fault of their own.

Ohioans' experiences of disempowerment are amplified by uncertainty about what is happening and how it affects them, something Michelle evinced as she paged through records of her fruitless calls to company representatives and state regulators. She may have been inspired by the consent form I collected

\footnotetext{
${ }^{24}$ For information about MADION, see http://www.mothersagainstfracking.org/ [accessed January 4 2013].

${ }^{25}$ Interview, February 27, 2012.

${ }^{26}$ Interview, February 29, 2012.
} 
from each participant in my research project when she described the lack of information regarding fracking's actual effects: "We are one big experiment here," she complained, "and we have not given the authority to anybody to make us participants in this study." Because the composition of fracking fluid has typically been considered proprietary information, companies are rarely required to disclose what chemicals they use and in what quantities. As a result, individuals lack the knowledge needed to make informed and effective decisions. Indeed, ethnographic accounts of environmental disasters suggest that secrecy undermines trust in experts and hampers residents' ability to make sense of their own situation, thereby contributing to perceptions of disempowerment; as Button points out, laypeople are frequently "made to feel as if they are inadequate arbitrators of uncertainty while scientists, corporations, and government agencies attempt to gain control over calamity" (2010:167). Confounding the case of fracking, ambiguity about the effects of chemical exposure enables both sides of the debate to engage in highly politicized "discourses of justification" that (mis)represent real risks (Cartwright 2013:203) and pro-fracking narratives position neoliberal economic cost-benefits assesses as the only legitimate discourse on the subject, thus marginalizing those who interpret fracking's impacts in non-economic terms (Finewood and Stroup 2012).

The notion of ontological security, advanced by Anthony Giddens, is valuable for making sense of how disempowerment and uncertainty interact to produce perceptions of vulnerability. An ontologically secure individual can be confident in the "the continuity of their self-identity and in the constancy of the surrounding social and material environments of action" and trust that the persons and things they encounter are essentially reliable (Giddens 1990:92). But, Giddens argues, "when routines are shattered—for whatever reason-anxieties come flooding in, and even very firmly founded aspects of the personality of the individual may become stripped away and altered" (1990:98). Research on responses to environmental degradation has revealed that when trust, power, and control are absent, the psychological trauma resulting from ontological insecurity can be even more detrimental than the physical hazards under scrutiny. Based on a comparative study of landfill citing cases in southern Ontario, for instance, Wakefield and Elliott suggest that adverse impacts "relate as much to the process of siting a landfill as to the perceived impacts of the landfill itself," especially when study participants have little opportunity for meaningful participation (2000:1151). A similar dynamic has been noted among residents of the Flammable shantytown in Argentina (Auyero and Swistun 2009). In Ohio, as we have seen, formerly confident and secure citizens feel they can no longer control critical components of their lives. At the same time, a large number of people are experiencing the stress of vulnerability for the first time. As noted above, scholars investigating the differential effects of environmental degradation within and between social groups have used the term vulnerability to underscore the sociopolitical construction of risk and the fact that some people are more likely than others to be adversely impacted by the same event (Oliver-Smith 2009, 2011). Here, I also use the term in a more colloquial—although inseparable—manner to indicate individuals' lived experience of feeling at risk and susceptible.

Above all else, Ohioans who oppose shale energy development fear for the health of their families. Several interviewees told me they are convinced their land is already contaminated, although they were unable to define the quality and quantity of contamination and unsure what its tangible effects might be. Many have experienced severe psychological unease associated with environmental health concerns. Susan, the former Broadview Heights resident whose epigraph opens this article, shared the painful story of a generator installed only 89 feet $(27 \mathrm{~m})$ from her home that vented directly toward her family's air conditioning unit. One summer morning in 2009, everyone in her home-including two young children-awoke with intense headaches and nausea. A trained automotive engineer, Susan suspects the symptoms were caused by carbon monoxide poisoning. She later suffered serious health problems, which she attributes to the anxiety surrounding the incident and the subsequent stressful period in which she and her husband felt it necessary to abandon their home. In fact, they rented an apartment as soon as possible and have no intention of returning to what was once their dream home. ${ }^{27}$ Even after three years and relocation to another state, Susan's trust that the world will grant her and her loved ones long and healthy lives has been fundamentally destabilized.

\footnotetext{
${ }^{27}$ Interview, February 29, 2012.
} 
In some cases, the anticipation of shale energy development has proven nearly as disruptive. As Roy Rappaport posits, "when information concerning physical events, rather than the events themselves, act as stimuli, the physical events need not have yet occurred for there to be significant effects" (1994:161). In other words, apprehension and anxiety must be acknowledged as actual impacts of environmental degradation. Cheryl from Union County-a place where significant shale energy development has not yet taken place-said it has already had negative impacts. "It has undermined my security," she stated, "I really am nervous, very nervous and scared that our land isn't gonna be able to continue to provide what we need to survive...It's incredibly stressful, incredibly stressful." ${ }^{28}$ Others were more specific about the uncertainties that now cloud their visions of the future. Christine, owner of an Athens County restaurant that features locally-grown sustainable produce, said everything she has worked for could soon be undone. "It's the danger of not knowing what is gonna happen," she explained:

I could name at least a dozen farms that I buy from that are not interested in the drilling but they're surrounded by people who do want the money for drilling. And so they don't even know whether they're gonna be able to stay in business or want to live in the area if it does become polluted or noisy. Everything is up in the air.

Furthermore, Christine told me, for years she considered purchasing farmland on which to grow some of the food for her restaurant, but she no longer looks at the world in the same way. "I don't look at the landscape anymore," she said, "I guess I see it now as an unknown." 29

Stuart Kirsch writes of the profound malaise Yonngom people living downstream from the environmentally disastrous Ok Tedi mine feel when look upon their land: "Their landscape is no longer a site of productivity, but a scene of loss," he observes, "instead of providing them with security, it confronts them with new, indecipherable risks" (2006:200). In the context of the Exxon-Valdez oil spill, which devastated Alaska's Prince William Sound in 1989, Gregory Button reported that many people he spoke to "experienced depression, loss of sleep, and other symptoms of bereavement, though no human lives had been lost" (2010:47). And, at Grassy Narrows, we have seen how mercury contamination similarly unsettled formerly taken-for-granted visions of a secure and sustaining world, as "the suspicion of pijipowin [poison] and the feeling of loss of control over the environment ran like a strong undercurrent beneath the tangible and measurable effects of the contamination" (Shkilnyk 1985:179). The magnitude of environmental degradation caused by shale energy development in Ohio has not yet approached the severe damage that transpired in these cases. Yet the human impacts sound oddly familiar. For Ohioans who oppose shale energy development, landscapes that until recently provided the promise of sustenance, stability, renewal, and relaxation have, in the face of apparently uncontrollable and unknowable environmental changes, been replaced by landscapes of disempowerment and vulnerability.

\section{The new politics of environmental degradation}

"Todos Somos Indios del Mundo" read the banner draped across a building abutting México City's Zócalo. We are all indigenous citizens of the world. This is something the Zapatistas-indigenous Chiapans and non-indigenous supporters alike-who marched on Mexico City to petition for the constitutional recognition of indigenous rights know well (Figure 5). When they evoke the analogy of the miner's canarythe caged bird that alerts coal miners to the presence of poisonous gasses-Native North American scholars convey a similar message: While indigenous people may be among the first to suffer, the devastating results of environmental degradation are certain to spread (Weaver 2010). And even as Anishinaabe anti-clearcutting activists at Grassy Narrows took direct action to protect their own land, health, and culture, they

\footnotetext{
${ }^{28}$ Interview, January 18, 2012.

${ }^{29}$ Interview, February 20, 2012.
} 
simultaneously took stock of the bigger picture, acknowledging that their crusade was not just for their community, nor just for indigenous people elsewhere, but for everyone. ${ }^{30}$

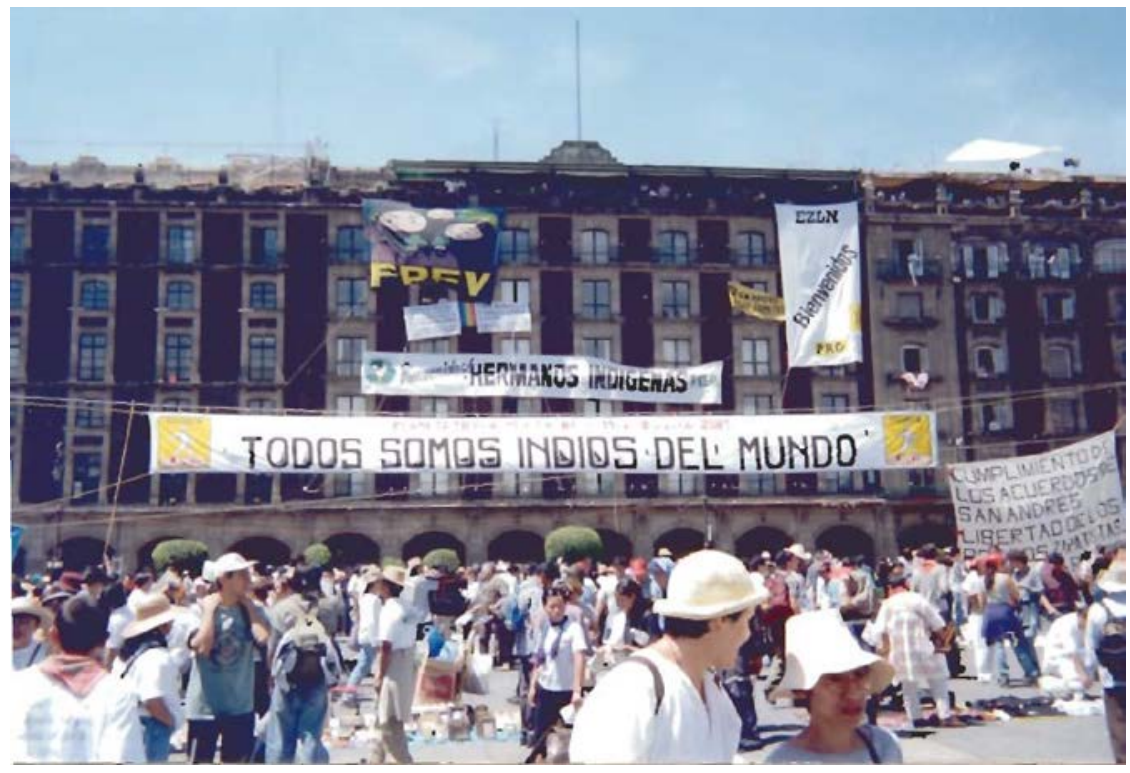

Figure 5: Banner at the Zapatista march on México City. March, 2001. Source: Glen David Kuecker, used with permission of the photographer.

Today, as environmental degradation reaches new groups of people in new places, so too does the realization that there is but one world-one physical system that sustains us all, regardless of the sociopolitical constructions that unite or divide us, privilege or marginalize us. As environmental degradation alters physical systems and bodies, it also alters our understandings of and interactions with this world. The stories of environmental degradation — and the experiences of disempowerment and vulnerability around which they revolve-introduced in this article have clear commonalities that speak for themselves. In both cases, externally imposed environmental changes have had critical and catastrophic effects on how people envision their environments and how they live their lives. In both cases, perceived parallels between degraded environments and the physical bodies of those who inhabit them contribute to a sense of urgency capable of inspiring individuals' actions. And, in both cases, issues that initially appear environmental turn out to be sociopolitical, as rights are violated and vulnerability produced. Yet, given my conviction that looking to locales of unexpected environmental degradation can reveal new political economic patterns, it is in the divergences that some of the most interesting implications lie. As Thomas Hall and James Fenelon observe, the key difference between indigenous movements (like the movement against clearcutting at Grassy Narrows) and mainstream social movements (like the anti-fracking movement in Ohio), is that the latter are not just about distributing slices of the pie differently or adjusting the recipe; they are about saying "no thank you" and refusing the pie altogether (2008:2; see also Fenelon and Hall 2009).

In world-systemic terms, Grassy Narrows is a peripheral place, distant from geographic, political, and economic centers of power and absent from all but the most detailed maps. As across Canada's north, perceptions of northwestern Ontario's boreal forest as a vacant resource frontier have long excused the exploitation of natural resources in the name of national sacrifice (Bocking 2011; Henry 2002). Following centuries of colonization, First Nation residents are used to being marginalized and disadvantaged. They have come to expect, although certainly not accept, injustice, which they know now sometimes takes

\footnotetext{
${ }^{30}$ Fieldnotes, May 29, 2003. A Grassy Narrows activist shared a similar statement with a local reporter in October 2003 (Aiken 2003).
} 
environmental forms. While global market economic participation has been gradually increasing since the fur trade era, Grassy Narrows residents remain largely outside of this system (Willow 2012). With a mixed local economy that blends land-based subsistence and cash acquired through wage labor and government transfer payments, community members' articulation with Canadian and transnational networks continues to be an ongoing and selective process of refusal, adoption, and adaptation. Even as some residents endeavor to reinforce the ties that bind them to Western industrial society, others work at least as hard to distance themselves from it-to remain literally and figuratively off the grid. ${ }^{31}$ Grassy Narrows activists' recent decisions - most notably the anti-clearcutting campaign initiated in 2002 - speak to their determination to demonstrate cultural distinctiveness, political sovereignty, and autonomous peoplehood. When they say their rights are being violated, these are the things they have in mind.

Ohio conversely occupies a much more central-and much more privileged-political economic position, a fact that became especially obvious when I visited some of the places shale energy development has entered urban and suburban residential areas. These places are home to full participants in global capitalism, to people who earn decent salaries and use their income to purchase a wide variety of goods and services. To people who grew up believing their governments and guidelines would protect them and uphold their rights. Unlike at Grassy Narrows, where environmental degradation originated with distant decisionmakers and benefits-assessments radically alien to local community members, shale energy development in Ohio is pitting neighbor against neighbor as some sign leases for personal financial gain. For many antifracking activists, the sense of community breakdown and social recession are palpable. Also unlike at Grassy Narrows - where people position themselves outside of and against a political economic system they oppose-people in Ohio are by and large upset about being disempowered within this system. When they speak of their rights being violated, they mean the civil rights that form the core of liberal democratic values: individual rights to liberty, freedom, and justice for all.

\section{Conclusion}

We know that neither the causes nor the effects of social and environmental inequity can be understood independently. Environmental justice scholars, advocates, and activists have taught us to expect to see environmental degradation where people are sociopolitically disadvantaged. We are not accustomed to seeing it where we are now. It has long been common for resource-extractive and pollution-intensive industries to regard the natural environment as outside their arena of social accountability. With Western ontology's division of nature from culture, bodies from minds, and environment from humanity extended to produce a parallel divide between indigenous others (considered part of wild nature) and modern selves (believed to be apart from and above it) (Latour 1993), this kind of thinking has served to justify the mistreatment of so-called peripheral peoples for centuries. But the boundary between those who benefit from environmental degradation and those who bear its burdens seems to have shifted so that today almost all of us are outside corporate and public decision-makers' realm of responsibility. As one Ohio resident declared, "There's very little value placed on the lives of the people that are in the areas that are being drilled right now." ${ }^{32}$ This is the new politics of environmental degradation.

World-systems analyst Glen Kuecker (2007) anticipates that as our complex global system becomes unglued-something he feels is already taking place-historical injustices will intensify. Writing for a popular audience, Jarrod Diamond (2005) similarly speculates that even without a dramatic collapse of industrial civilization, symptoms of systemic failure are likely to spread to ever-increasing segments of the world's population. In fact, economic data indicate that the divide between the elite and everyone else is increasing; between 1979 and 2007, income inequality rose 33\% (Congressional Budget Office 2011). ${ }^{33}$ I don't have the breadth or depth of comparative data needed to say for certain that the human impacts resulting

\footnotetext{
${ }^{31}$ Fieldnotes, June 5, 2003.

${ }^{32}$ Cheryl (Union County resident), interview, January 18, 2012.

${ }^{33}$ In that period, income grew by 275 percent for the top 1 percent of households, by 65 percent for the next 19 percent, by just under 40 percent for the next 60 percent, and by only 18 percent for the bottom 20 percent (Congressional Budget Office 2011).
} 
from shale energy development in Ohio are not anomalous. But the possibility that the appearance and experience of environmental degradation in unexpected places could signal significant systemic changes is certainly worth paying attention to. It is my hope that this article inspires additional studies that address the impacts and implications of environmental degradation, not only where we expect to encounter it, but in unanticipated places as well.

As buying freedom from the effects of industrial effluent becomes increasingly expensive, individuals' health, quality of life, and relationships to the natural world are likely to suffer. The consequences for global sustainability could be catastrophic. In a society already plagued by widespread ignorance of the fact that humans are neither invincible nor exempt from basic ecological principles, shale energy development is prompting people to withdraw from places they once loved in order to protect themselves physically and emotionally. Given that this type of disconnect tends to encourage unsustainable and irresponsible decisions (Cronon 1995), a problematic cycle of environmental disassociation and degradation is poised to continue. But I need to believe in an upside with the potential to counter this gloomy prognosis. Ohio residents I met over the course of my research — anti-fracking activists, nonprofit affiliates, and community leaders aliketold me most members of their communities formerly paid little attention to environmental issues. But they also said the looming threat of environmental degradation has catalyzed a new kind of consciousness. People are beginning to appreciate critical connections between their own wellbeing and the environment that makes it possible. They are coming to see fossil fuel dependency and policies that put corporations ahead of ecological integrity as serious social problems. Grassy Narrows residents have known for a long time that global capitalism does not work in their favor. They have-both by circumstance and by choice-remained at its margins. Increasingly, people in positions of political economic privilege are also starting to feel that this system - their own system-is no longer working for them. Perhaps, more and more of us will choose to say "no thank you" and aspire instead to create the resilient, sustainable communities on which humanity's future will depend.

\section{References}

Aiken, M. 2003. Clearcuts slice at the heart of Native lifestyle. Kenora Enterprise. October 13.

Auyero, J. and D.A. Swistun. 2009. Flammable: environmental suffering in an Argentine shantytown. New York: Oxford University Press.

Beck, U. 1992. From industrial society to risk society: questions of survival, social structure, and ecological enlightenment. Theory, Culture and Society 9: 97-123.

Bender, B. 2002. Time and landscape. Current Anthropology 43(Supplement): S103-S112.

Biersack, A. 2006. Red river, green war: the politics of place along the Porgera River. In A. Biersack and J.B. Greenberg (eds.). Reimagining political ecology. Durham, NC: Duke University Press. Pp233280.

Biersack, A. and J.B. Greenberg (eds.). 2006. Reimagining political ecology. Durham, NC: Duke University Press.

Blaikie, P. and H. Brookfield. 1987. Land degradation and society. London: Methuen.

Bocking, S. 2011. Indigenous knowledge and the history of science, race, and colonial authority in northern Canada. In A. Baldwin, L. Cameron, and A. Kobayashi (eds.). Rethinking the Great White North: race, nature, and the historical geographies of whiteness in Canada. Vancouver: University of British Columbia Press. Pp39-61.

Brosius, J.P. 2006. Between politics and poetics: narratives of dispossession in Sarawak, East Malaysia. In A. Biersack and J.B. Greenberg (eds.). Reimagining political ecology. Durham, NC: Duke University Press. Pp281-322.

Bullard, R.D. 1990. Dumping in Dixie: race, class, and environmental quality. Boulder, CO: Westview Press.

Bullard, R.D. (ed.). 2005. The quest for environmental justice: human rights and the politics of pollution. San Francisco: Sierra Club Books. 
Button, G. 2002. Popular media reframing of man-made disasters: a cautionary tale. In A. Oliver-Smith and S.M. Hoffman (eds.). Catastrophe and culture: the anthropology of disaster. Santa Fe, NM: School of American Research Press. Pp143-158.

Button, G. 2010. Disaster culture: knowledge and uncertainty in the wake of human and environmental catastrophe. Walnut Creek, CA: Left Coast Press.

Cairns, A.C. 2000. Citizens plus: Aboriginal peoples and the Canadian state. Vancouver: University of British Columbia Press.

Canada (Federal Government). 1966 [1871-4]. Treaty No. 3 between her majesty The Queen and the Saulteaux tribe of Ojibbeway Indians at the Northwest Angle on the Lake of the Woods with adhesions. Ottawa: Queens Printer.

Canada (Federal Government). 1986. Grassy Narrows and Islington Indian bands mercury pollution claim settlement act. Ottawa: Department of Justice Canada.

Cartwright, E. 2013. Eco-risk and the case of fracking. In S. Strauss, S.Rupp, and T. Love (eds.). Cultures of energy: power, practices, technologies. Walnut Creek, CA: Left Coast Press. Pp201-212.

Checker, M. 2005. Polluted promises: environmental racism and the search for justice in a southern town. New York: New York University Press.

Cocklin, J. 2013. Oil, gas case heading to Ohio top court will spotlight local control. Online September 20 2013 [accessed November 29 2013]. http://www.vindy.com/news/2013/sep/20/local-authority-overdrilling-at-issue-a.

Cole, L.W. and S.R. Foster. 2001. From the ground up: environmental racism and the rise of the environmental justice movement. New York: New York University Press.

Congressional Budget Office. 2011. Trends in the distribution of household income between 1979 and 2007. Online [accessed December 18 2012]. http://www.cbo.gov/sites/default/files/cbofiles/attachments/1025-HouseholdIncome.pdf.

Cosgrove, D.E. 1984. Social formation and symbolic landscape. Madison: University of Wisconsin Press.

Cronon, W. 1995. The trouble with wilderness; or, getting back to the wrong nature. In W. Cronon (ed.). Uncommon ground: rethinking the human place in nature. New York: W.W. Norton. Pp 60-90.

De Rijke, K. 2013a. Hydraulically fractured: unconventional gas and anthropology. Anthropology Today 29(2): 13-17.

De Rijke, K. 2013b. The Agri-gas fields of Australia: black soil, food and unconventional gas. Culture, Agriculture, Food, and Environment 35(1): 41-53.

Diamond, J. 2005. Collapse: how societies choose to fail or succeed. New York: Viking Penguin.

The Economist. 2012. America's bounty: Gas works. Online July 142005 [accessed December 7 2012]. http://www.economist.com/node/21558459.

Edelstein, M.R. 2004. Contaminated communities: coping with residential toxic exposure, second edition. Boulder, CO: Westview Press.

Edwards, B. 1995. With liberty and environmental justice for all: the emergence and challenge of grassroots environmentalism in the United States. In B. Taylor (ed.). Ecological resistance movements: the global emergence of radical and popular environmentalism. New York: State University of New York Press. Pp35-55.

Erasmus, G. and J. Sanders. 1992. Canadian history: an Aboriginal perspective. In D. Engelstad and J. Bird (eds.). Nation to nation: Aboriginal sovereignty and the future of Canada. Concord, ON: Anansi Press. Pp3-11.

Erikson, K. and C. Vecsey. 1990. A report to the people of Grassy Narrows. In C. Vecsey and R.W. Venables (eds.). American Indian Environments: ecological issues in Native American history. Syracuse, NY: Syracuse University Press. Pp152-161.

Fenelon, J.V. and T.D. Hall. 2009. Indigenous peoples and globalization: resistance and revitalization. Boulder, CO: Paradigm Press. 
Finewood, M.H. and L. J. Stroup. 2012. Fracking and the neoliberalization of the hydro-social cycle in Pennsylvania's Marcellus Shale. Journal of Contemporary Water Research and Education 147(1): $72-79$.

Fortun, K. 2001. Advocacy after Bhopal: environmentalism, disaster, new global orders. Chicago: University of Chicago Press.

Friedman, J. 1994. Cultural identity and global process. London: Sage Publications.

Giddens, A. 1990. The consequences of modernity. Stanford: Stanford University Press.

Gottlieb, R. 1993. Forcing the spring: the transformation of the American environmental movement. Washington, DC: Island Press.

Grinde, D.A. and B.E. Johansen. 1995. Ecocide of Native America: environmental destruction of Indian lands and people. Santa Fe, NM: Clear Light Publishers.

Hall, T.D. and J.V. Fenelon. 2008. Indigenous movements and globalization: what is different? What is the same? Globalizations 5(1): 1-11.

Hallowell, A.I. 1955. Culture and experience. New York: Schocken Books.

Hallowell, A.I. 1975. Ojibwa ontology, behavior, and world view. In D. Tedlock and B. Tedlock (eds.). Teachings from the American earth: Indian religion and philosophy. New York: Liveright. Pp141178.

Harada, M. and M. Hanada, T. Miyakita, T. Fujino, K. Tsuruta, A. Fukuhara, T. Orui, S. Nakachi, C. Araki, M. Tajiri, and I. Nagano. 2005. Long-term study on the effects of mercury contamination on two indigenous communities in Canada (1975-2004). Tadashi Orui, trans. Research on Environmental Disruption 34(4).

Henry, J.D. 2002. Canada's boreal forest. Washington, DC: Smithsonian Institution.

Hirsch, E. 1995. Landscape: between space and place. In E. Hirsch and M. O'Hanlon (eds.). The anthropology of landscape: perspectives on place and space. Oxford: Oxford University Press. Pp130.

Homer-Dixon, T. 1994. Environmental scarcities and violent conflict: evidence from cases. International Security 19(1): 5-40.

Hudgins, A. 2013. Fracking's future in a coal mining past: subjectivity undermined. Culture, Agriculture, Food and Environment 35(1): 54-59.

Johnston, B.R. (ed.). 1994. Who pays the price? The sociocultural context of environmental crisis. Washington, DC: Island Press.

Johnston, B.R. 1997. Introduction: life and death matters at the end of the millennium. In B.R. Johnston (ed.). Life and death matters: humans rights and the environment at the end of the millennium. Walnut Creek, CA: AltaMira. Pp9-21.

Kenora Daily Miner and News. 1986. Parliament passes settlement act covering Grassy, Islington bands. Kenora Daily Miner and News. 5 June.

Kenora Daily Miner and News Staff and the Canadian Press. 1984. \$10 Million package approved. Kenora Daily Miner and News. 19 September.

Kirsch, S. 2006. Reverse anthropology: indigenous analysis of social and environmental relations in New Guinea. Stanford: Stanford University Press.

Kuecker, G. 2007. The perfect storm: catastrophic collapse in the $21^{\text {st }}$ century. The International Journal of Environmental, Cultural, Economic and Social Sustainability 3: 1-10.

LaDuke, W. 1999. All our relations: native struggles for land and life. Cambridge, MA: South End Press.

Latour, B. 1993. We have never been modern. Cambridge, MA: Harvard University Press.

Martinez-Alier J., Anguelovski I., Bond P., Del Bene D., Demaria F., Gerber J.-F., Greyl L., Haas W., Healy H., Marín-Burgos V., Ojo G., Porto M., Rijnhout L., Rodríguez-Labajos B., Spangenberg J., Temper L., Warlenius R. and I. Yánez. 2014. Between activism and science: grassroots concepts for sustainability coined by Environmental Justice Organizations. Journal of Political Ecology 21: 19-60. 
Miller, J.R. 1991. Skyscrapers hide the heavens: a history of Indian-White relations in Canada. Toronto: University of Toronto Press.

Mitchell, W.J.T. 1994. Landscape and power. Chicago: University of Chicago Press.

Nesper, L. 2002. The walleye war: the struggle for Ojibwe spearfishing and treaty rights. Lincoln: University of Nebraska Press.

Nichols, J.D. and E. Nyholm. 1995. A concise dictionary of Minnesota Ojibwe. Minneapolis: University of Minnesota Press.

Niezen, R. 1998. Defending the land: sovereignty and forest life in James Bay Cree society. Boston: Allyn and Bacon.

Ohio Substitute House Bill Number 278. 2004. 125th General Assembly. Ohio.

Oliver-Smith, A. 1996. Anthropological research on hazards and disasters. Annual Review of Anthropology 25: 303-328.

Oliver-Smith, A. 2009. Anthropology and the political economy of disasters. In E.C. Jones and A.D. Murphy (eds.). The political economy of hazards and disasters. Lanham, MD: AltaMira Press. Pp11-28.

Oliver-Smith, A. and S.M. Hoffman. 2002. Introduction: why anthropologists should study disasters. In A. Oliver-Smith and S.M. Hoffman (eds.). Catastrophe and culture: the anthropology of disaster. Santa Fe, NM: School of American Research Press. Pp3-22.

Omoweh, D.A. 2005. Shell Petroleum Development Company, the state and underdevelopment of Nigeria's Niger Delta: a study in environmental degradation. Trenton, NJ: Africa World Press.

Pelling, M. 2001. Natural disasters? In N. Castree and B. Braun (eds.). Social nature: theory, practice, and politics. Malden, MA: Blackwell. Pp170-188.

Perry, S.L. 2011. Energy consequences and conflicts across the global countryside: North American agricultural perspectives. Forum on Public Policy 2011(2).

Perry, S.L. 2013. Using ethnography to monitor the community health implications of onshore unconventional oil and gas developments: examples from Pennsylvania's Marcellus Shale. New Solutions 23(1): 33-53.

Pulido, L. 1996. Environmentalism and economic justice: two Chicano struggles in the southwest. Tucson: University of Arizona Press.

Rappaport, R.A. 1994. Human environment and the notion of impact. In B.R. Johnston (ed.). Life and death matters: human rights and the environment at the end of the millennium. Walnut Creek, CA: AltaMira. Pp157-169.

Rebuffoni, D. 1977. Mercury in the northwoods. Minneapolis Tribune Picture Magazine. 11 September.

Reed, R. 2008. Forest dwellers, forest protectors: indigenous models for international development. Boston: Allyn and Bacon.

Rich, R.C., M. Edelstein, W.K. Hallman, and A.H. Wandersman. 1995. Citizen participation and empowerment: the case of local environmental hazards. American Journal of Community Psychology 23(5): 657-676.

Robbins, P. 2004. Political ecology: a critical introduction. Malden, MA: Blackwell.

Sawyer, S. 2004. Crude chronicles: indigenous politics, multinational oil, and neoliberalism in Ecuador. Durham, NC: Duke University Press.

Shkilnyk, A. 1985. A poison stronger than love: the destruction of an Ojibwa community. New Haven, CT: Yale University Press.

Stewart, P.J. and A. Strathern. 2003. Introduction. In P.J. Stewart and A. Strathern (eds.). Landscape, memory and history. London: Pluto Press. Pp1-15.

Troyer, W. 1977. No safe place. Toronto: Clarke, Irwin, and Company. 
United States Environmental Protection Agency. 2012. Study of the potential impacts of hydraulic fracturing on drinking water resources: progress report. Online [accessed December 24 2012]. http://www.epa.gov/hfstudy/pdfs/hf-report20121214.pdf .

VanWynsberghe, R.M. 2002. AlterNatives: community, identity, and environmental justice on Walpole Island. New York: Allyn and Bacon.

Wakefield, S. and S.J. Elliott. 2000. Environmental risk perception and well-being: effects of the landfill siting process in two southern Ontario communities. Social Science and Medicine 50(2000): 11391154.

Wallerstein, I. 1974. The modern world system I: capitalist agriculture and the origins of the European world-economy in the sixteenth century. New York: Academic Press.

Wallerstein, I. 2004. World-systems analysis: an introduction. Durham, NC: Duke University Press.

Weaver, J. (ed.). 1996. Defending mother earth: Native American perspectives on environmental justice. Maryknoll, NY: Orbis Books.

Weaver, J. 2010. Notes from a miner's canary. Albuquerque: University of New Mexico Press.

Willow, A.J. 2009. Clear-cutting and colonialism: the ethnopolitical dynamics of indigenous environmental activism in northwestern Ontario. Ethnohistory 56(1): 35-67.

Willow, A.J. 2011. Conceiving Kakipitatapitmok: the political landscape of Anishinaabe anti-clearcutting activism. American Anthropologist 13(2): 262-276.

Willow, A.J. 2012. Strong hearts, native lands: the cultural and political landscape of Anishinaabe anticlearcutting activism. Albany: State University of New York Press.

Willow, A.J., D. Vilaplana, D. Sheeley, and R. Zak. 2014. The contested landscape of unconventional energy development: a report from Ohio's shale gas country. Journal of Environmental Sciences and Studies 4(1): 56-64.

Willow, A. and S. Wylie. 2014. Politics, ecology, and the new anthropology of energy: exploring the emerging frontiers of hydraulic fracking. Journal of Political Ecology 21: 222-236. 